Research Article

\title{
THE EXISTENCE OF FEMALE JOURNALISTS WEARING JILBAB IN THE TELEVISION MEDIA JAKARTA
}

Qisthy Rabathy, Elly Komala, Yanti Susila Tresnawati, Nik Nik Fadlah

Program Studi Ilmu Komunikasi, Universitas Pasundan, Bandung 40261, Indonesia

Article history:

Submission 01 October 2021

Revised 16 October 2021

Accepted 17 October 2021

*Corresponding author:

E-mail:

qisthyrabathy@unpas.ac.id

\begin{abstract}
Female who wear jilbab is now choosing journalists as a job. Journalists are a job which exists in the middle of the community who is assigned to provide information or news to the public. This is a very heavy profession and not everyone can do this profession. Uncertain journalist working hours added with various difficulties and obstacles in this profession make this profession identified as a male profession. This becomes a challenge for journalists wearing jilbab who choose this job as their profession.
\end{abstract}

Keywords: Female journalists wearing jilbab, Journalists, Jilbab

\section{Introduction}

The journalist profession is viewed by the community as one of the heaviest and the most difficult professions because it has many challenges, and a journalist is not infrequently must risk his life in order to obtain news that will be disseminated to the public. Journalists are not like workers in general because they are required to provide precise and accurate information and timeless work. It is not surprising that this job is viewed as the job of a male.

AJI (Aliansi Jurnalis Independen) has issued data on journalists who are members. In quantity, the number of female journalists in Indonesia is still low, until 2009 female journalists who were members of the AJI were around 234 people. Whereas the number of male journalists is around 1339 in 26 cities (the number of female journalists is only around 12\%). (Jurnal Perempuan, edition 67: 32).
However, as time goes by, the number of a female who work as journalists has increased. This can be seen from many female reporters and news anchors on television media. This also applies to female journalists who wear hijab.

Previously, jilbab had gotten discriminatory in the community. Someone who wears jilbab tends to be difficult to get a job compared to someone who doesn't wear it. Female who use jilbab are considered less attractive and not fashionable. They often get the choice to take off the jilbab if they want to get a job. It becomes one of someone's choices to refrain from wearing jilbab for work reasons. Whereas Indonesia is a country which upholds religious tolerance. However, why are there still parties who do not respect someone in their choice to wear jilbab? 
Along with the development of the times and the opened of public thought, female wearing jilbab is now accepted by the community. The trend of hijab is currently helping women look fashionable even though they wear a jilbab.

Jilbab women are now more valued in terms of finding a job. For example, many women who use jilbab currently have jobs outside the home, whether in the education, health and economic sectors. There are also jilbab women who work in a world of work that is usually identified and dominated by men, such as politicians or even journalists who also prove that jilbab can change people's views. However, there are still a number of agencies that give choices to women to take off their jilbab if they want to work for the agency, although it has rarely happened compared previous time.

The world of journalism is a hard world and also requires courage in carrying out its profession. This has become a challenge for jilbab female journalists. They are willing to get out of the "comfort zone" and prove that jilbab is not a barrier for those who are involved in the world of journalism that requires flexibility in their work.

A jilbab women who work as a journalist also breaks gender stereotypes on the community which states that women with jilbab must work in domestic areas, namely closed and less dangerous work. For example, work as a housewife. Although there are jilbab women who work on jobs that are associated with "male jobs", these women often get negative views from the community. This is what causes gender refraction and inequality in society.

Seeing the gaps that occur in the community, then come up women's emancipation initiated by R.A.Kartini. Kartini is considered an emancipation hero for Indonesian women who want gender equality. Furthermore, a view of feminism encourages women to get the same rights and degrees as men.

One of the most famous journalists with jilbab in the world is Noor Tagouri, the first jilbab female journalist in the United States who has worked for CBS Radio and CTV
News. As a Moslem and someone who wears a jilbab, she succeeded in changing the stigma of American society known for its Islamophobia towards Muslim women.

The presence of Noor Tagouri encourages jilbab female journalists in Indonesia, that someone who wears jilbab in a minority country can be successful as a professional journalist. Why not for those of us who live in a majority country?

In Indonesia, there are also jilbab news anchor figures that attract the attention of the public. As you need to know that although the majority of Indonesia's population is Moslem and many jilbab women with currently entering the world of journalism, many news anchors themselves still don't wear a jilbab. Jilbab journalists on television media are still widely placed to become reporters. The figure is the news anchor of TV One, namely, Yaumi Fitri.

On television media, the number of nonjilbab women journalists is more than female journalists who choose to wear a jilbab.

Of course, a jilbab female journalist is very extraordinary because she is willing to contribute on her profession as someone who is willing to give most of her time to search, cover, and convey information or news to the public, which is not easy and more challenging to do. And once again jilbab is not an obstacle for jilbab female journalists to continue to carry out their profession professionally.

\section{Method}

This study uses qualitative research methods, namely, the type of phenomenology. Phenomenology is research that focuses on a phenomenon or reality that appears to be explained.

Phenomenology research tries to explain or reveal the meaning of a concept or phenomenon of experience based on awareness that occurs in several individuals. Phenomenology is carried out in natural situations, so there is no limit in interpreting or understanding the phenomenon under study and the researcher is free to analyze the obtained data. 
Bogdan and Taylor as quoted in Moelong (2012: 4) reveal that qualitative research is a research procedure that produces descriptive data in the form of written or oral words from people and observable behavior.

\section{Results and Discussion Discrimination of Jilbab Journalists in their profession}

Jilbab women had experienced discrimination in the past. The community used to have narrow thoughts about jilbab, even in western countries, someone wearing jilbab was seen as strange or even considered a terrorist. Not only in western countries is discrimination against veiled women in effect, but also in Indonesia this discrimination has also prevailed. Women who wear jilbab are even difficult to find work, but even if they succeed in getting jobs, different treatments will be obtained by them, because in the old days women who did not wear jilbab were preferred and given special treatment than women who did not wear jilbab.

Discrimination does not only occur for women who get different treatment with men, but discrimination also occurs in jilbab, especially women who wear jilbab. This makes discrimination become more than just discrimination against women, and now jilbab becomes one of the reasons for carrying out such acts of discrimination.

Although the majority in this country is Moslem, the facts found by researchers in the field show that there is still discrimination in jilbab journalists on television media, even though their actions are small. This proves that there are still some people who have not been open to the existence of jilbab, and what is very unfortunate is that discrimination is carried out by the mass media which is the fourth pillar in the country.

The freedom of choice that has been given in the current reform era does not seem to be able to be followed by openmindedness of the public towards jilbab, even from previous cases, there are also women who are required to release their jilbab as job entry requirements. Although their actions did not reach this level, one of the informants interviewed by the researcher revealed that non-jilbab women were given more opportunities than jilbab women, and this was one of the acts of discrimination.

Discrimination should not be the main issue anymore for jilbab women, especially jilbab journalists. In a television media, discrimination should also be abolished. Wearing a jilbab for a journalist is a choice and television media must respect that decision. Jilbab journalists also deserve to be given the same opportunity as non-jilbab journalists and male journalists, because they are committed to their work.

Discrimination against women and jilbab journalists will gradually decrease or even disappear over time. Besides that discrimination can also be eliminated by the opening of thoughts on jilbab. Because negative thoughts about jilbab will make discrimination continue to occur in society. Jilbab women must be able to prove their ability to be able to work in the world of journalism, so that discrimination cannot occur.

\section{Difficulties of Jilbab Journalists}

Every profession must have its own difficulties, this also applies to a journalist. Time is one of the most important things and must be considered by the journalists because information and news never know time.

Most of the informants have been interviewed and said that the main difficulty in carrying out their profession while conducting a search and also covering the news was during the worship service. This is definitely very plausible where the journalists must be able to race against the time to worship and interviewing informants. This choice is very difficult because they are faced with the choice to carry out religious obligations and carry out work obligations. Not only applies to jilbab journalists, but it also applies to non-jilbab journalists who are Moslem. Even so, jilbab journalists have other difficulties that must 
be faced, namely tidying up their jilbab when they are finished carrying out worship.

During the live report, the results of research that has been conducted by jilbab journalists revealed that they had to wear jilbab that will not make the audience miss focus by paying attention to jilbab compared to the delivered news content. Therefore, they all revealed that the simple selection of jilbab must be done when carrying out the live report.

From the results of research that has been obtained, researchers can conclude that a profession as a journalist must be able to choose and sort out what should be prioritized, choosing a priority is an obligation for journalists, this must be done despite choosing religious or obligations to work. Jilbab journalists, as well as other adherents of Islamic religion, must always be istiqomah in performing worship, on the other hand, they also must always be prepared if at any time the speaker as the main source of news appears and uncertain.

From the explanation described above, it proves once again that the journalist profession is a very heavy profession and also not everyone wants and can run this profession. Only people who have a high commitment can run this profession. Therefore, a journalist must get high appreciation from the community because of the difficulties faced by the journalist in carrying out his profession.

\section{Actions Facing Challenges as Jilbab Female Journalists}

Journalists are professions that have a high degree of difficulty. Even to enter this profession is quite difficult. Someone who wants to become a journalist is required to have more abilities, such as having to have open thoughts and broad insights, so it is not surprising if journalists are seen as someone who has a high education. Besides having open thoughts and broad insights, a journalist must also have a strong mental and physical, so that it will be easier for a journalist carrying out his duties.
As explained earlier, intimidation and discrimination can happen to a journalist anytime and anywhere, a strong mentality allows a journalist to deal with the situation. A journalist must also have a strong physique, irregular working hours even up to 24 hours is a matter that must be faced by a journalist.

Difficulties also increased when the journalist did news coverage, as was informed by the informants interviewed, that the main difficulties faced by them at the time of reporting were during worship. They also have to face other obstacles that are considered quite heavy for the general public. Journalists will be faced with other obstacles that will await them every day, not infrequently there are some journalists who choose to leave their profession because they are not strong and are tired of facing these obstacles.

There are no differences in the obstacles faced by jilbab or non-jilbab journalists, all the obstacles faced by them are the same. However, jilbab journalists have other obstacles, namely regarding the issue of jilbab that must be considered when conducting a live report. In addition, another obstacle that must be faced by jilbab journalists is discrimination in the midst of their work. Discrimination has gradually diminished, but in the midst of society today discrimination against jilbab women still has its cases.

From the jilbab journalists who have been interviewed, they have all been involved in this profession for quite a long time, from 3 to 5 years. During their duty as journalists, they revealed that they had faced all the difficulties when carrying out their duties. In addition to the difficulties and obstacles they faced, they all chose to stay in this profession because indeed it was their passion from the beginning. In addition, another reason they persist in their profession is that they enjoy their jobs.

This reasoning can be used as a very appropriate action for jilbab and non-jilbab journalists to keep on wrestling with their profession. Since the beginning, it has been 
explained that to become a journalist must have a strong mentality. The advantage of strong mentality is what makes a person who works as a journalist can survive in the midst of difficulties and obstacles in her profession.

Jilbab Provisions as News Anchor or Reporter Jilbab women who have penetrated into the journalist profession today are many, both those who work as producers, editors, creative teams, news anchors, reporters, and so on. But what is seen and the most prominent is news anchor and reporters, because they usually work in front of the screen. This can be seen from the number of jilbab journalists who broadcast live to convey information to the public. However, most jilbab journalists that we see on television are more likely to work as reporters when compared to news anchor, even today news anchors that wear jilbab can still be counted on the fingers. To be a news anchor on television, the selection is more stringent when compared to public television stations. Nevertheless, it seems that there are still many television stations that have not produced jilbab news anchor.

Informants interviewed by researchers were jilbab journalists who all worked as reporters. Most of them revealed that the reason where they work more uses nonjilbab news anchor compared to those wearing jilbab to look neutral. And this is indeed the policy of the office. As for a reporter, there are no provisions like news anchor.

From the explanations that have been revealed by the informants, it turns out there are still many television stations that make a neutral reason to determine a news anchor. It is undeniable that neutral is one of the conditions that must be possessed by television media, and that reason does have good intentions. However, it is better if television media does not see from "jilbab" to make journalists a news anchor. Television media should look more at the abilities an individual has as a journalist than a religious symbol.

\section{Community Views of Jilbab Female Journal- ists}

The presence of jilbab which is currently increasing prevalent in the community seems to provide a distinct advantage for jilbab journalists. If in the past the people were still very reluctant and had their own views (especially negative views) on journalists who were wearing jilbab, however, at this time the community did not have a negative view of jilbab journalists.

All jilbab journalists interviewed by researchers revealed that the community never gave a negative view of them working as a journalist. Instead, they have the advantage of being jilbab journalists. As stated by one of the informants that the jilbab made her more appreciated when doing coverage, especially coverage that covered activities from other religions.

This proves that the longer the community increasingly appreciates jilbab journalists. Although there is still a relatively small amount of discrimination, the positive view and appreciation given by the community towards the jilbab journalists can eliminate the prevailing discrimination. The change of people's views on the jilbab is also inseparable from the hijab trend which is currently booming both in the world and in Indonesia so that people are more openminded to jilbab.

But besides all that, there are still various parties who intimidate jilbab journalists, and this is very unfortunate. But in addition, all the intimidation and discrimination that comes from the community is very small compared to when the public's thoughts about jilbab are still not open as now and now more people appreciate the jilbab journalists compared to intimidating and discriminating against the jilbab journalists.

\section{Jilbab Women Journalists Defining the World of Journalism as Their Profession}

Journalist profession known as a heavy profession and always filled with various difficulties and obstacles has indeed become a challenge for anyone who is involved in this profession. The informants 
who are jilbab journalists have different motives or reasons when deciding to enter the profession. As with motives, they also find their own meaning that is different when they wrestle this world.

The meaning they get is based on the experience as a journalist that they have been through. Of course, the meaning cannot be obtained only by doing the search and coverage of the news once or twice, but the meaning is obtained after they have long been involved in this profession. The longer they engage in this profession, the more difficulties and obstacles they will encounter, the more meaning they will gain.

Journalist profession is a different profession in general, in this profession, as a journalist they are taught to behave politely when conducting interviews with informants, giving information actually adding a personal opinion, and they are also required to be able to choose the top priority in carrying out their profession. Jilbab journalists have more meaning for them, moreover, jilbab journalists must be able to face obstacles that are even two or three times heavier when compared to non-jilbab journalists. But as previously stated, they never saw the jilbab as an obstacle in undergoing this profession. High commitment is one of the things that must be owned by jilbab journalists who have chosen this profession besides everything that later on will be passed by them.

\section{Conclusion}

Jilbab journalists have different motives or reasons when deciding to wear a jilbab. Most of the informants in this study revealed that syar'i was the reason they were wearing a jilbab, other than that other reasons revealed besides syar'i were due to environmental factors and family background.

Informants who have been interviewed by researchers have similar reasons for working in the journalistic world, namely because of their aspirations and have longstanding interests in the journalist profession. The majority of informants inter- viewed by researchers did not have a formal journalistic education background, but they learned from the environment of other organizations and non-formal environments. Only the fourth informant has a journalistic formal education background.

Discrimination that occurs in jilbab journalists is currently still valid, but the treatment is not as big as when the jilbab has not become a trend in the community. In addition to the discrimination that can be faced by jilbab journalists, another thing that can be faced by them is intimidation when carrying out tasks that can occur at any time and is carried out by several groups of people who are less open to the jilbab journalists.

Jilbab journalists have difficulties when performing worship where they have to choose priorities between carrying out religious obligations and work obligations. This is a major difficulty and often occurs not only for jilbab journalists but also for most Moslem journalists. In addition, another difficulty that is possessed is that jilbab journalists must choose the most suitable hijab when doing a live report.

There are several challenges that will be faced by jilbab journalists in the face of challenges. Enjoying the profession that has been involved is the answer from jilbab journalists who chose this job. Changing the negative view of society, and enjoying every coverage assigned to them is also something done by jilbab journalists in enjoying their profession.

In the current era of globalization, it turns out that jilbab is still a provision to be a news anchor compared to reporters. It caused by television media which wants something neutral and there is no symbol of any religion. While for television media, reporters are more open to jilbab journalists.

In this study, all the informants who have been interviewed are jilbab journalists who have long struggled in their work, so they have their own meaning and are not the same as each other, because they have different experiences. 


\section{References}

Cangara, Hafied H. 2002. Pengantar Ilmu Komunikasi. Jakarta : PT Raja Grafindo.

Departemen Pendidikan Nasional. 2014. Kamus Besar Bahasa Indonesia Cetakan ke Delapan Belas Edisi IV. Jakarta : Gramedia Pustaka Utama.

Effendy, Onong Uchjana. 2003. Ilmu, Teori, Dan Filsafat Komunikasi. Bandung : PT Citra Aditya Bakti.

2002. Ilmu Komunikasi Teori Dan Praktek. Bandung : PT Remaja Rosdakarya.

Hasyim, Syafiq. 2005. Pengantar Feminisme dan Fundamentalisme Islam. Yogyakarta : LKiS.

Luviana. 2012. Jejak Jurnalis Perempuan. Jakarta : Aliansi Jurnalis Independen.

Mulyana, Deddy. 2004. Ilmu Komunikasi : Suatu Pengantar. Bandung : PT Remaja Rosdakarya.

2012. Ilmu Komunikasi : Suatu Pengantar. Bandung : PT Remaja Rosdakarya.
2014. Ilmu Komunikasi : Suatu Pengantar. Bandung : PT Remaja Rosdakarya.

Moleong, L.J.2010. Metodologi Penelitian Kualitatif. Bandung : PT Remaja Rosdakarya.

Sugiyono. 2018. Metodologi Penelitian Kuantitatif dan Kualitatif dan R\&D. Bandung : Alfabeta.

Sumadiria, Haris. 2005. Jurnalistik Indonesia, Menulis Berita dan Feature, Paduan Praktis Jurnalis Profesional. Bandung : PT Remaja Rosdakarya.

\section{Other Sources :}

Journal

Wahyuningsih, Fahmi. (2013). Perjuangan Tokoh Emansipasi Perempuan Indonesia Dan Jerman. Jurnal Studi Perempuan, 9(1), 48 